\title{
Social wasps of two wetland ecosystems in brazilian Amazonia (Hymenoptera, Vespidae, Polistinae)
}

\author{
Orlando Tobias SILVEIRA', Salustiano Vilar da COSTA NETO², Odete Fátima M. da SILVEIRA³
}

\begin{abstract}
In Brazilian Amazonia, 20 genera and more than 200 species of polistine wasps are recorded. Local faunas with 70 to 80 species are usually found in non floodable forest environments. However, a variety of wetlands exist in the region, the most expressive in surface area being varzea systems. In this paper, information is presented on polistines from two areas of wetlands in the Brazilian states of Amazonas and Amapá. These are reciprocally compared and also with nearby terra firme locations. Collecting methods consisted of active search for nests, handnetting and automatic trapping of individuals. Forty-six species of 15 genera were collected in Mamirauá, AM, most being widespread common wasps. However, five species deserve special mention in virtue of rarity and/or restricted distribution: Metapolybia rufata, Chartergellus nigerrimus, Chartergellus punctatior, Clypearia duckei, and Clypearia weyrauchi. In Região dos Lagos, AP, 31 species of 9 genera were collected, nearly all being common species with the exception of some Polistes, like P. goeldi and P. occipitalis. Even though less rich than vespid faunas from terra firme habitats, the Mamirauá fauna proved to be quite expressive considering limitations imposed by the hydrological regime. In Região dos Lagos, however, the very low diversity found was below the worst expectations. The virtual absence of otherwise common species in environments like tidal varzea forests along Araguari River is truly remarkable. The causes of low diversity are probably related to isolation and relative immaturity of the region, allied to strong degradation of forested habitats.
\end{abstract}

KEYwORDS: Polistine wasps, Varzea, Tidal varzea, Amazonas, Amapá

\section{Vespas sociais de duas áreas úmidas na Amazônia brasileira (Hymenoptera, Vespidae, Polistinae)}

\begin{abstract}
RESUMO
Vinte gêneros e mais de 200 espécies de vespas sociais são registrados na Amazônia brasileira. Faunas locais com 70 a 80 espécies são usualmente encontradas em florestas não inundáveis. Entretanto, uma grande variedade de áreas úmidas existe na região, com destaque para os sistemas de várzea. Neste artigo, apresentamos dados sobre vespas de duas áreas úmidas nos estados brasileiros do Amazonas e Amapá. Estes são também comparados às informações de áreas de terra firme adjacentes. Métodos de coleta consistiram em busca ativa por ninhos e coleta manual e com armadilhas de indivíduos. Quarenta e seis espécies de 15 gêneros foram coletadas em Mamirauá, AM, a maioria delas comuns e amplamente distribuídas. Entretanto, cinco merecem destaque por sua raridade ou distribuição restrita, ou ambas: Metapolybia rufata, Chartergellus nigerrimus, Chartergellus punctatior, Clypearia duckei e Clypearia weyrauchi. Na Região dos Lagos, AP, 31 espécies de 9 gêneros foram encontradas, quase todas comuns, exceto por algumas de Polistes, como P. goeldi and P. occipitalis. A fauna de Mamirauá é muito expressiva, embora menos rica que as de florestas de terra firme, a despeito dos limites impostos pelo regime hidrológico. Por outro lado, na Região dos Lagos, a diversidade encontrada esteve abaixo das piores expectativas. Verdadeiramente notável foi a virtual ausência na várzea estuarina do Rio Araguari de espécies comuns em outros lugares e ambientes no Neotrópico. As causas dessa baixa diversidade são provavelmente relacionadas ao isolamento e relativa imaturidade da região, aliadas à forte degradação dos ambientes florestados.
\end{abstract}

PALAVRAS-CHAVE: Vespas polistíneas, Várzea, Várzea estuarina, Amazonas, Amapá

\footnotetext{
1 Pesquisador Adjunto I, Museu Paraense Emílio Goeldi, Departamento de Zoologia. Av. Perimetral da Ciência s/n, Campus de Pesquisas, Coordenação de Zoologia - Guamá. CEP 66040-170 - Belém - PA - Brasil. Telefone: (91) 32176115 Fax: (91) 32741615 e-mail: orlando@museu-goeldi.br

2 Pesquisador II - Flora e Fauna, Instituto de Pesquisas Científicas e Tecnológicas do Estado do Amapá. e-mail: salustiano.neto@iepa.ap.gov.br

3 Professor da Universidade Federal do Amapá. e-mail: silveira@ufpa.br
} 


\section{INTRODUCTION}

Neotropical social wasps are mainly representatives of Polistinae, a cosmopolitan group comprising 25 genera and more than 900 species. The taxon is more diversified in the tropical and subtropical regions of the world (Carpenter $e t$ al., 1996; Richards, 1971, 1978). In Brazilian Amazonia, 20 genera and more than 200 species have been recorded for the tribes Polistini, Mischocyttarini and Epiponini. These wasps are popular on account of their aggressive defensive behavior and beauty of nest architecture, both aspects representing emergent social features. They are mainly carnivorous, the food items consisting of arthropod preys, primarily insects of various orders but with a great prevalence of lepidopteran caterpillars. Larval and adult diets also include nectar and other vegetal juices. Most species construct aerial nests, height from the ground varying with species preferences and nest site availability. However, most species of the genus Agelaia build hidden nests in cavities within trees or in the ground (Richards, 1978).

Neotropical polistines are most diverse in forest environments. Species richness usually ranges from 70 to 80 species but with higher numbers occurring in some places (Silveira, 2002). In Brazil, Richards (1978) reported 88 species for the area around the base camp of the 1968 Royal Geographic Society expedition, localized in the northeast of the state of Mato Grosso. That region is transitional between the Cerrado and Amazonia biomes, and its natural vegetation cover has been largely removed in the recent years. However, the largest number of species so far recorded for a local wasp fauna in the Neotropics has been found elsewhere $700 \mathrm{~km}$ north of Richards' "base camp", in Serra dos Carajás, in Pará state (collection of the Museu Goeldi, Belém). Silveira (2002) reported 102 species, but this number has been recently revised and the Carajás list actually includes 115 species.

Figures of species richness like those mentioned above usually refer to non floodable forest environments. In Brazilian Amazonia such terra firme forests take up $80-90 \%$ of the area, growing on the Tertiary basin as well as on older terrains of the Brazilian and Guyana cratonic shields. However, a variety of wetlands exist in the region (Pires \& Prance, 1985), the most expressive in surface area being floodplain varzea systems that occupy a total extent of $100,000 \mathrm{~km}^{2}$ (Wittmann et al., 2004). Holocene varzea occurs on young terrains formed along white-water rivers by deposition of sediments originated with erosion of Andean and Pre-Andean soils. To the east of the basin, on the region of the Amazon estuary also occur the so-called "tidal varzea", where a daily inundation cycle superimposes to the annual flooding periodicity (Cattanio $e t$ al., 2002; Parolin et al., 2004).

Information on social wasp faunas from two widely separated areas of lacustrine wetlands in the Brazilian states of
Amazonas and Amapá (Figure 1) is here presented. These wasp faunas are compared reciprocally and also with nearby terra firme locations so that quantitative and qualitative aspects can be appreciated in relation to factors like flood regime, extent of forest cover and anthropogenic impacts. The two data sets were independently collected as parts of separate projects. Information from Amazonas state was acquired during a survey of insects of the "Estação Ecológica de Mamirauá" (now Sustainable Development Reserve) made along three expeditions in September/1993, January-February/1994, and June-July/1994 (sponsored by Sociedade Civil Mamirauá and Museu Paraense Emílio Goeldi). Data from Amapá state resulted from a general biological inventory performed in the "Região dos Lagos", along two expeditions in April-May/2004 and October-November/2004 (supported by the Brazilian Ministry of Environment - MMA/PROBIO).

\section{THE AREAS}

The Mamirauá reserve is located between the Japurá and upper Amazon rivers (in Brazil, the stretch of river from the Brazilian border to the mouth of the Negro River is called the Solimones River) near their confluence in the state of Amazonas (Figures 1 and 2). The reserve encompasses a total area of 1,124,000 ha of varzea lands, representing a corridor of Quaternary terrains surrounded by the older Tertiary Terra firme domains at north and south of the Amazon. At the confluence of the two rivers the total distance across of varzea is about $50 \mathrm{Km}$, but may be still wider at other points. Climate is super-humid (Af) without a dry season, but precipitation varies widely along the year with rainfall from December to March being three times larger that verified between July and October (Ayres, 1993). Mean annual rainfall

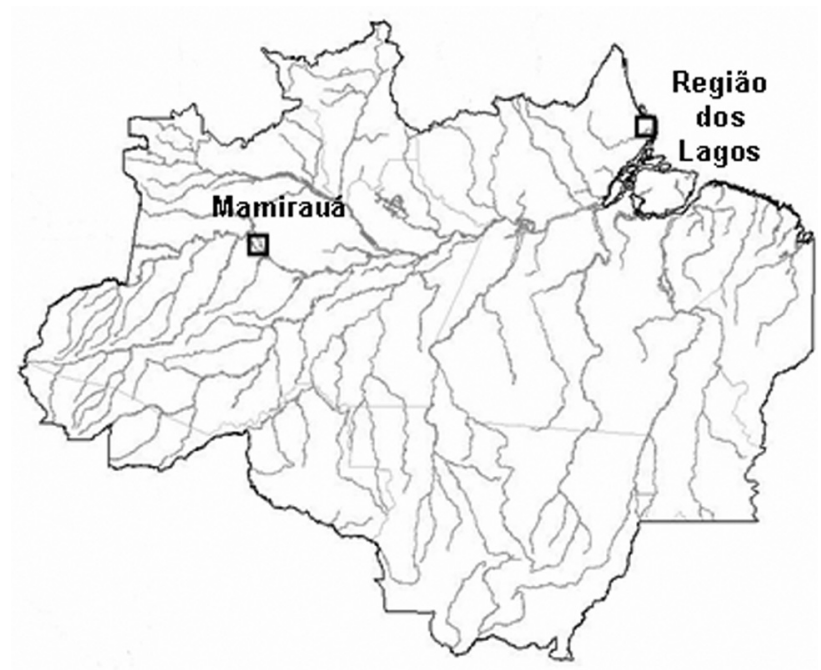

Figure 1 - Map of Brazilian Amazonia showing position of studied areas: Mamirauá in Amazonas state, and Região dos Lagos in Amapá state. 
in Mamirauá was about 3,000 $\mathrm{mm}$ for the years of 1996 to 2000 (Wittmann, 2004). Mean monthly temperature varies between 25 and $28^{\circ} \mathrm{C}$. Amplitude of flooding may be up to 12 meters, the higher water peaks occurring from May to June (Ayres, 1993). Floristic composition, tree species richness and structure of forests are strongly linked to location along the flood-level gradient (Ayres, 1993; Wittmann, 2004). In Mamirauá, three main vegetation types are recognized: (1) high varzea forest ("restinga alta" of authors) occurs on more elevated terrains, being flooded for 2 to 4 months under a 1 to 2.5 meters water column. High varzea forest is the species richest among varzea physiognomies representing about $12 \%$ of total forest area, being similar in structure to terra firme forests; (2) low varzea forest ("restinga baixa") is the prevalent vegetation kind in about $85 \%$ of forested area, being flooded for 4 to 6 months under water depths around 5 meters. The understory is more open, and species richness is lower than in high varzea forest; (3) chavascal is the type occurring on lower terrains flooded for 6 to 8 months under water depths up to 7 meters, consisting mostly of low shrub vegetation, sporadically presenting emergent trees.

The second area, Região dos Lagos in Amapá state comprises a large sector of the coastal plains between rivers Araguari and Amapá (Figures 1 and 3). The region is very complex consisting of a multiplicity of habitats including mangrove, tidal varzea forest, flood grassland-lake, savanna, and forests. A large part of the area is protected within a federal conservation unity, the "Reserva Biológica do Lago Piratuba"

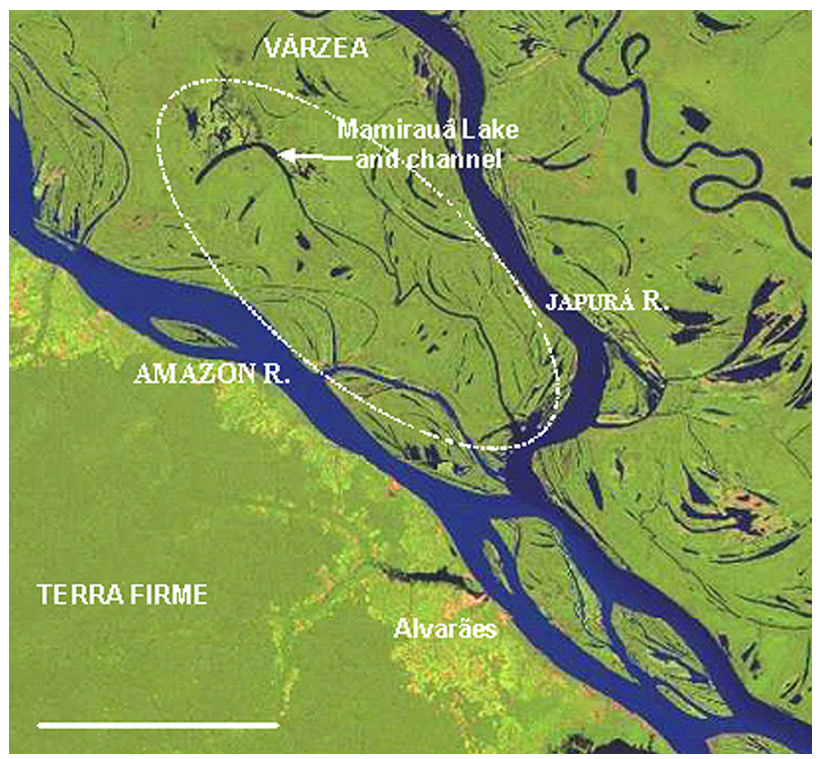

Figure 2 - Composite satellite picture of the confluence of Amazon and Japurá rivers, AM, Brazil, showing the várzea (Mamirauá) and terra firme (Alvarães) sampled localities; scale bar is $15 \mathrm{~km}$. (adapted from Miranda \& Coutinho, 2004; image acquisition date: 1999-2000) with 395,000 ha. Geomorphologic history of the Amapá coastal platform has been very complex and dynamic, with large changes occurring within relatively small time intervals, under the strong influence of the Amazon's enormous sediments discharge. Coastal terrains are formed by both fluvial and marine sediments (Silveira, 1998, 2006; Santos et al., 2005). Silveira (1998) postulates that one main aspect of the regional landscape, i.e. the strings of lakes, may be an endproduct of reversed drainages formed by tectonic basculating movements of marginal blocks. Climate is humid (Am) with a short dry season from September to November. Annual rainfall is above $3,250 \mathrm{~mm}$, and mean monthly temperature stays around $26^{\circ} \mathrm{C}$, with the minimum temperature never falling below $22^{\circ} \mathrm{C}$. Level of flood over grassland areas and lakes is dependent on regional rainfall and the hydrologic regimes of rivers as the Araguari, Tartarugalzinho, Flexal, and Amapá Rivers. High waters occur from May to June, while the lowermost levels coincide with the drier period from September to November. In addition to the annual flood cycle, floodplains along the lower courses of rivers suffer the daily influence of tides. Tidal bores (pororocas) may be an important factor reorganizing the landscape along some of the mentioned rivers (Santos et al., 2005).

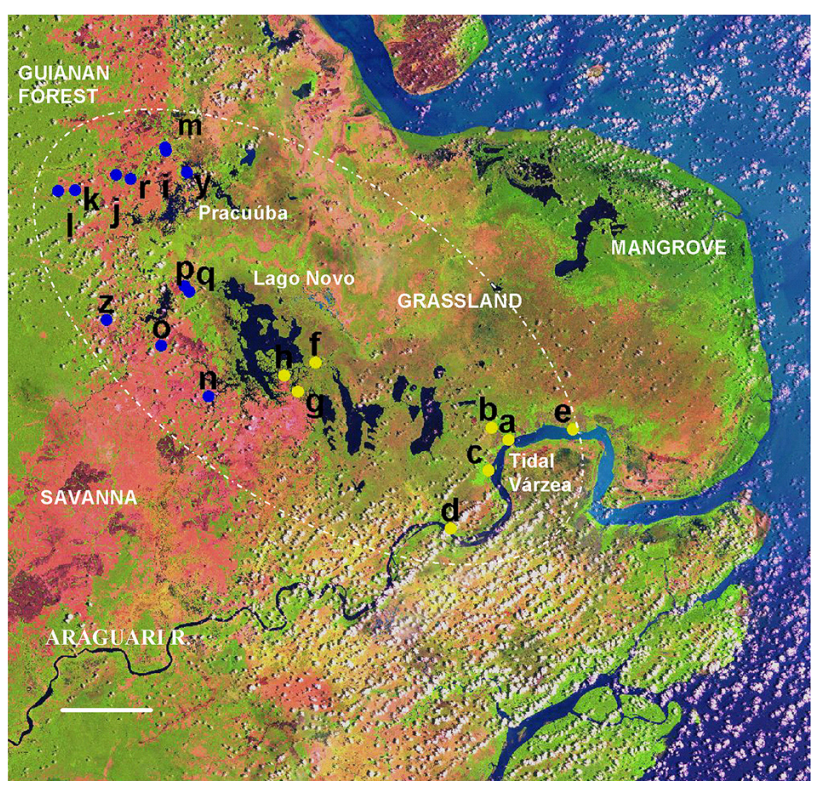

Figure 3 - Satellite image of Região dos Lagos, AP, Brazil, showing sampled subregions: tidal várzea of Araguari River, Lago Novo and Pracuúba; scale bar is $15 \mathrm{~km}$ (image provided by SEMA/AP; acquisition date: 1999). Legends for 19 sampling sites as follows: a- mouth of Tabaco Creek; b- Japim in Tabaco Creek; c- Piranhas Creek; d- Vista Alegre; e- Monte Sião; f- Comprido Lake; g- São Benedito; h- Caranã; i- Tucunaré; j- 2 Km west of highway BR 156; k- Pernambuco settlement; l- end of Pernambuco road; m- Pantaleão's farm; n- Lago Novo road; o- Entrada da Mata; p- Rildo's farm; q- Mata do Flexal; y- Pracuúba city; z: Tartarugalzinho city 


\section{CONSERVATION STATUS}

The varzea in Mamirauá has a long history of human occupation but this apparently never occurred in high densities. With the decadence of natural rubber exploitation in the Solimôes River, in the first half of twentieth century, various settlements were installed in the region so that human activities began to have larger impact on natural populations (Queiroz, 2005). However, because of the limiting conditions imposed by floods in Mamirauá and its isolation from Terra firme areas, large-scale cattle ranching has not been an important factor of environmental modification. Currently, a large fraction of the region is protected and managed as a Sustainable Development Reserve. There are about 1800 local people living within and around the reserve depending on fish, some agriculture and timber extraction (Koziell \& Inoue, 2006). In the Região dos Lagos, however, impacts from human settlements are more diversified and stronger, especially those coming from illegal hunting and fishing. In some places, water buffalo ranching has produced extensive modification of the landscape, from deforestation to disruption of original drainage patterns. Very importantly, also, in the dry season from September to November fires are quite frequent, rapidly spreading on the flammable vegetation at the bottom of dry lakes.

\section{MATERIAL AND METHODS}

Collecting activities in Mamirauá had as main access pathways the varzea channel leading from R. Japurá $\left(3^{\circ} 07^{\prime}\right.$

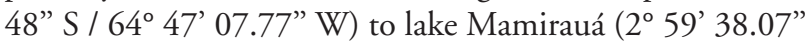
S / 64 $\left.56^{\circ} 08.37^{\prime \prime} \mathrm{W}\right)$, and another neighbor channel the "Paraná do Apara" (301' 47.98" S / 64 51' 17.03" W). Total linear distance traveled while collecting from mouth of Japurá to Lake Mamirauá and other nearby lakes and channels is estimated as $40 \mathrm{~km}$ (Figure 2).

In Região dos Lagos samples were collected in three subregions: (1) floodplains of Araguari River (10 19' 23” N / $50^{\circ} 16$ ' 51 " W) and meridional lakes; (2) mixed areas around “Lago Novo" Lake (1' 26’ 43” N / 50 34' 59” W); (3) region of Pracuúba city (1'44’37.45” N / 50 47’ 4.03” W) - Flexal River. The whole set of collecting sites spreads along a 100 $\mathrm{km}$ stretch of land just across Região dos Lagos (Fig. 3). In the Araguari subregion, collecting was made in tidal varzea forests, flood grasslands, pastures, and village buildings. In Lago Novo, efforts were mainly directed at areas of forested mounds (tesos florestados), savannas, and a relatively large area of low forest on the west margin of the lake. In the Pracuúba subregion, collecting was made in varzea forests along Flexal River, on village buildings, and in various points of the transition between savanna and Terra firme forest localized west of the BR-163 highway (Figure 3).
For comparison purposes, data on social wasps from Terra firme forest environments were collected in places adjacent to each of the main study areas. In Amazonas, the terra firme wasp fauna was sampled in forest fragments localized about $7 \mathrm{~km}$ south of the city of Alvarães (3 12' 51.65" S / 640 48' 46.40 " W) on the south bank of the Amazon and $10 \mathrm{~km}$ distant from Mamirauá (Figure 2). In Amapá, data on terra firme wasps were collected about $15 \mathrm{~km}$ west of the city of Pracuúba, along the north-south transition between the huge continuous block of Guyanan forests and Amapá coastal savannas (Figure 3).

Collecting methods were similar in both localities consisting of the general procedures used by wasp collectors, i.e. searching for nests, handnetting and automatic trapping of flying individuals in interception traps.

- Active search. Wasps and their nests were searched for along walks across natural vegetation, by the margins of roads, on human constructions, or by boat along river or lake margins. Three to four persons acted as collectors, using hand nets sometimes attached to long wood or metal poles to reach colonies located high in trees. Information from people inhabiting the areas (especially from local field assistants) was very important for finding colonies.

- Interception traps. Four kinds were used (Silveira, 2002): (1) Six-meter Malaise trap with two collecting chambers (SMM); (2) Two-meter Malaise trap with one collecting chamber (TMM); (3) Suspended Malaise trap at 1,5 m from the ground (SUML); (4) Suspended Malaise trap at 10-20 $\mathrm{m}(\mathrm{SUMH})$.

Table 1 - Comparative information on methods and collecting effort employed in each of the areas surveyed for social wasps in Amazonas and Amapá states, Brazil. SMM: Six-meter Malaise trap with two collecting chambers; TMM: Twometer Malaise trap with one collecting chamber; SUML: Suspended Malaise trap at $1.5 \mathrm{~m}$ from the ground; SUMH: Suspended Malaise trap at 10-20 m; LT: Light trap; trapping effort given in trap-day units.

\begin{tabular}{lccc}
\hline & \multicolumn{2}{c}{ Amazonas } & Amapá \\
\cline { 2 - 4 } Effort Indicator & $\begin{array}{c}\text { Mamirauá } \\
\text { (varzea) }\end{array}$ & Alvarães (terra firme) & $\begin{array}{c}\text { Região dos } \\
\text { Lagos }\end{array}$ \\
\hline $\begin{array}{l}\text { Number of } \\
\text { expeditions }\end{array}$ & 3 & 3 & 2 \\
$\begin{array}{l}\text { Days of } \\
\text { searching work }\end{array}$ & 45 & 6 & 20 \\
$\begin{array}{l}\text { Distance traveled } \\
\text { (km) }\end{array}$ & 40 & 7 & 100 \\
\hline Trapping effort & 76 (6 sites) & $49(4$ sites $)$ & - \\
\hline SMM & - & - & $48(9$ sites $)$ \\
TMM & $83(10$ sites) & $83(4$ sites $)$ & - \\
SUML & 97 (10 sites) & $48(4$ sites $)$ & $42(9$ sites $)$ \\
SUMH & - & - & $2(2$ sites $)$ \\
\hline LT & & &
\end{tabular}


*In the Amazonas localities only, a bait of octenol (Merck) was fastened to the cloth of traps for attraction of horseflies (Tabanidae), another surveyed taxon. The bait consisted of a small tubular vial containing a strap of filter paper soaked in octenol. No published study is known to us showing efficiency of this substance in attracting wasps.

- Light trap (LT). This was used in a complementary fashion for capture of nocturnal wasps of the genus Apoica (Pickett e Wenzek, 2007), in Amapá localities only.

Information in Table 1 shows that if collecting methods were basically similar, collecting effort varied a lot between studied areas in several respects, especially as to the total number of days of fieldwork, and the total area explored. The inventory work in Região dos Lagos followed the logics of a Rapid Ecological Assessment (Fonseca, 2001) in which a certain number of points should be explored within a relatively large and heterogeneous region, trying to cover most of environmental variability in a rather short period (Fig. 3). Added to logistic difficulties, this resulted into a somewhat rarified data table in which sampling points are normally nonequivalent regarding both environmental attributes and collecting effort. On the other hand, collecting effort in Mamirauá was considerable, with exploration of a far more homogeneous varzea landscape (Figures 2 and 6) for a wider seasonal spectrum, and with much larger intensity of searching or trapping activities (Table 1). For different reasons, however, collecting procedures could not be planned so as to produce data structured in comparable independent samples, a condition at least approximated by Silveira (2002) in an inventory in Caxiuanã, in Pará state. A basic deficiency of unstructured collecting work is that species accumulation curves (Colwell \& Coddington, 1994) can hardly be generated, thus limiting proper evaluation of the success level achieved in discovery of species.

All the material collected in Mamirauá and Alvarães, AM, is deposited in the Museu Paraense Emílio Goeldi (MPEG). Specimens from Região dos Lagos, AP, are in the Instituto de Pesquisas Científicas e Tecnológicas do Amapá (IEPA) and Museu Goeldi.

\section{RESULTS AND DISCUSSION}

\section{AMAZONAS STATE}

Fourty-six (46) species of 15 genera were collected in Mamirauá (Table 2), most of them being widespread common wasps. However, at least five of the species deserve special mention in virtue of rarity or restricted distribution or both: Metapolybia rufata was at the time (1994) only known from the type series from Napo, Peru; Chartergellus nigerrimus is also recorded from western Amazonia only; Chartergellus punctatior, Clypearia duckei and Clypearia weyrauchi are known to be more widely distributed (Richards, 1978, and data from MPEG collection), but are rarely collected. Twenty-three species $(50 \%$ of the total) were captured with interception traps, and an equal number was exclusively found during walks in forest tracks through the dry season, and by boat along the margins of varzea channels and in forest interior during the flooded period.

The frequencies of species collected in traps - 26 interception traps in total -(Figure 4) should be taken as raw estimates of species abundances because in many instances traps were too close to each other, so that they hardly can be considered as independent samples (individuals of a single colony captured by two or more traps within a restricted

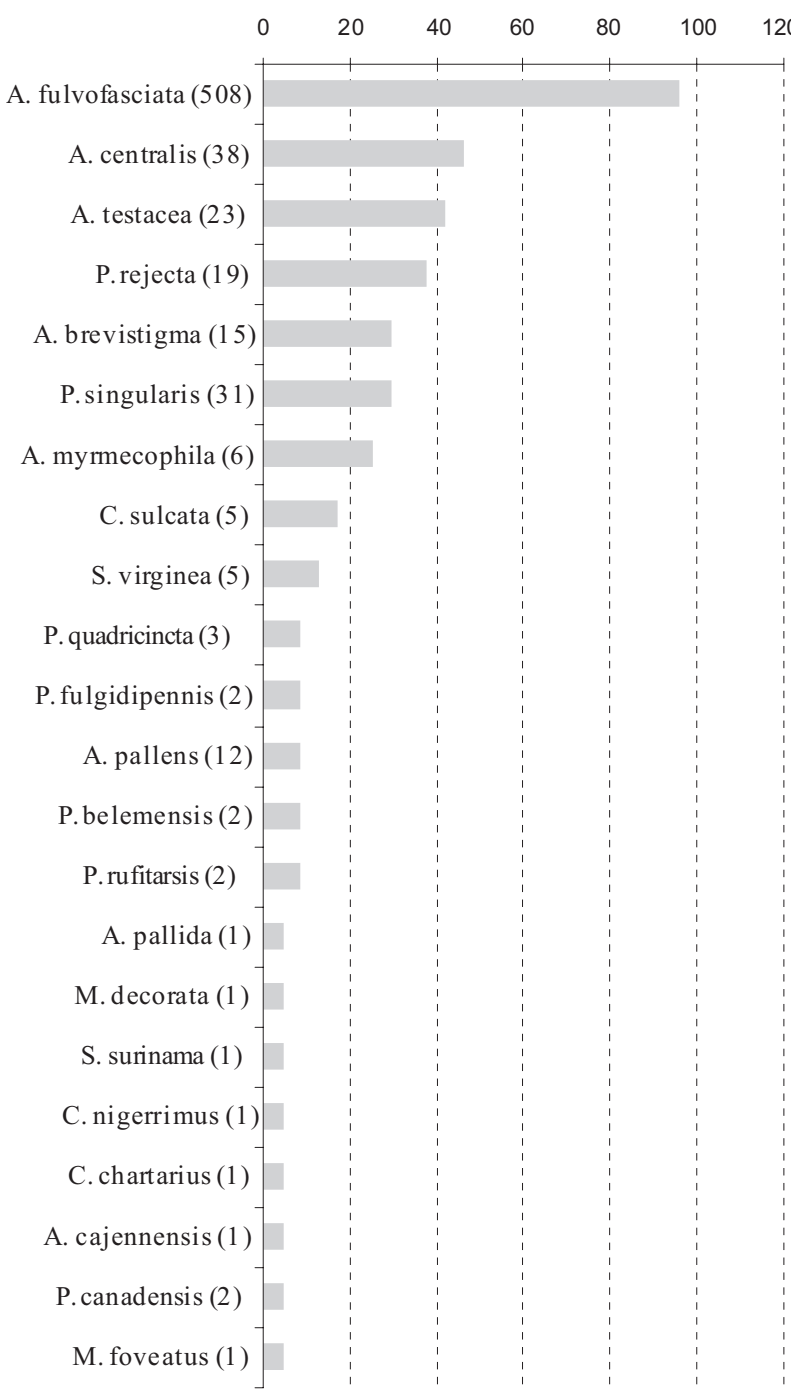

Figure 4 - Social wasp species composition and frequency in samples from Malaise and Suspended traps installed in várzea habitats, in Mamirauá AM, Brazil, along three expeditions in 1993 and 1994. Number of collected individuals is shown in parenthesis. 
Table 2 - Forty-six species of social wasps found in the varzea of Mamirauá, AM, Brazil, within a discontinuous period of 45 days of field work in the years 1993 and 1994. Letters indicate one of three kinds of traps used, M: Malaise, L: Suspended Low, H: Suspended High; "C" means that colonies were found.

\begin{tabular}{|c|c|c|c|}
\hline \multicolumn{2}{|c|}{ Species } & \multirow{2}{*}{$\begin{array}{c}\text { Trap } \\
\mathrm{H}\end{array}$} & \multirow[t]{2}{*}{ Search } \\
\hline 1 & Polistes canadensis (L.) & & \\
\hline 2 & P. versicolor (Olivier) & & \# \\
\hline 3 & Mischocyttarus lecointei (Ducke) & M & \\
\hline 4 & M. foveatus Richards & & $\#$ \\
\hline 5 & M. imitator (Ducke) & & $\#(C)$ \\
\hline 6 & M. injucundus (Saussure) & & $\#(C)$ \\
\hline 7 & M. synoecus Richards & & $\#(C)$ \\
\hline 8 & M. alfkenii (Ducke) & & $\#(C)$ \\
\hline 9 & Apoica pallida (Olivier) & $\mathrm{H}$ & \\
\hline 10 & A. thoracica (Buysson) & & $\#(C)$ \\
\hline 11 & A. pallens (F.) & & $\#$ \\
\hline 12 & A. flavissima Van der Vecht & & $\#(C)$ \\
\hline 13 & Agelaia testacea (F.) & HLM & $\#$ \\
\hline 14 & A. fulvofasciata (Degeer) & HLM & \\
\hline 15 & A. cajennensis (F.) & M & \\
\hline 16 & A. brevistigma Richards & HLM & \\
\hline 17 & A. myrmecophila (Ducke) & $\mathrm{HM}$ & \\
\hline 18 & A. centralis (Cameron) & HLM & $\#$ \\
\hline 19 & Angiopolybia pallens (Lepeletier) & LM & \\
\hline 20 & $\begin{array}{l}\text { Pseudopolybia compressa (de } \\
\text { Saussure) }\end{array}$ & & $\#(C)$ \\
\hline 21 & Parachartergus smithii (de Saussure) & & $\#(C)$ \\
\hline 22 & P. fraternus (Gribodo) & & $\#(C)$ \\
\hline 23 & P. fulgidipennis (de Saussure) & L & $\#(C)$ \\
\hline 25 & Chartergellus nigerrimus Richards & $\mathrm{L}$ & $\#(C)$ \\
\hline 26 & C. punctatior Richards & & $\#(C)$ \\
\hline 24 & Protopolybia chartergoides (Gribodo) & & $\#$ \\
\hline 27 & Brachygastra augusti (de Saussure) & & $\#(C)$ \\
\hline 28 & B. bilineolata Spinola & & $\#(C)$ \\
\hline 29 & B. lecheguana (Latreille) & $\mathrm{L}$ & $\#(C)$ \\
\hline 30 & Chartergus chartarius (Olivier) & $H$ & \\
\hline 31 & Polybia bicyttarella Richards & & $\#$ \\
\hline 32 & P. belemensis Richards & L & \\
\hline 33 & P. quadricincta de Saussure & M & \\
\hline 34 & P. rufitarsis Ducke & L & \\
\hline 35 & P. rejecta (F.) & HL M & $\#(C)$ \\
\hline 36 & P. striata (F.) & & \\
\hline 37 & P. dimidiata (Olivier) & & $\#$ \\
\hline 38 & P. singularis Ducke & HLM & $\#(C)$ \\
\hline 39 & Synoeca virginea (F.) & HLM & \\
\hline 40 & S. surinama (L.) & $\mathrm{H}$ & \\
\hline 41 & Metapolybia decorata (Gribodo) & $\mathrm{H}$ & $\#(C)$ \\
\hline 42 & M. rufata Richards & & $\#(C)$ \\
\hline 43 & M. cingulata $(\mathrm{F})$. & & $\#$ \\
\hline 44 & Clipearia sulcata (de Saussure) & $\mathrm{H}$ & $\#(C)$ \\
\hline
\end{tabular}

\begin{tabular}{llcc}
\hline Species & Trap & Search \\
\hline 45 & C. weyrauchi Richards & & $\#(\mathrm{C})$ \\
46 & C. duckei Richards & $\#(\mathrm{C})$ \\
\hline $\begin{array}{l}\text { Number of species registered with } \\
\text { method }\end{array}$ & 23 & 23 \\
\hline & & (exclusive only) \\
\hline
\end{tabular}

area will inflate frequency records of that given species; furthermore data from different kinds of traps with possibly slightly different capture selectivities have been mixed). Agelaia fulvofasciata was the most frequently trapped wasp in the varzea being registered in almost $100 \%$ of

the traps. Second and third ranked species had only about half that frequency. Among the species with frequencies higher than $20 \%$ (i. e. collected in more than 5 traps), there are five Agelaia and only two Polybia. Fifteen or $65 \%$ of the species had very low frequencies, being captured in one or two traps only. Data from traps seem to reflect with some accuracy the signal strength of truly common species, but do not allow to recognize small differences between rarer species. While Chartergellus nigerrimus, Polybia rufitarsis and Agelaia cajennensis seemed indeed to be rare in Mamirauá, Chartergus chartarius and Metapolybia decorata were common species whose nests were rather easily found along the margins of channels. Clypearia weyrauchi was not trapped one single time but its nests were fairly commonly found in searches by river margins. Water bodies certainly play a great influence in the local distribution patterns of several species like Apoica pallida, Polybia rejecta, Parachartergus smithii, Metapolybia decorata, Clypearia weyrauchi and others. Stands of emergent aquatic macrophytes seem to be important foraging sites for social wasps in the varzea, and individuals of species like Polybia singularis and Polybia rejecta were often seen exploring this habitat.

\section{COMPARISON VARZEA X TERRA FIRME}

The species collected in fragments of Terra firme forest near Alvarães consisted of 42 species from 12 polistine genera (Table 3). These slightly lower numbers are consequence of the reduced collecting effort, $30 \%$ less trapping effort and very few active searching (Table 1). Close inspection of Table 3 and figure 5, however, makes readily apparent that the number of species trapped in Alvarães was actually larger than in Mamirauá in both relative and absolute terms. One sees also that Agelaia fulvofasciata was again the most frequent species but in a not so extreme way. The set of most frequent species included a larger number of Polybia, and Angiopolybia pallens was more frequent there than in the varzea. Another aspect possibly revealing differences between the two kinds of environment refers to general number of trapped individuals which in Alvarães was only 30\% that verified in Mamirauá, 
Table 3 - Forty-two species of social wasps found in terra firme forest fragments in Alvarães, AM, Brazil, within a discontinuous period of 45 days of field work in the years 1993 and 1994. Letters indicate one of the three kinds of traps used, M: Malaise, L: Suspended Low, H: Suspended High; "C" means that colonies were found.

\begin{tabular}{|c|c|c|c|}
\hline & Species & Trap & Search \\
\hline 1 & Polistes pacificus (F.) & & \# \\
\hline 2 & P. bicolor Lepeletier & & \# \\
\hline 3 & P. versicolor (Olivier) & & \# \\
\hline 4 & Mischocyttarus flavicans (F.) & & \# \\
\hline 5 & M. labiatus (F.) & M & \# \\
\hline 6 & M. surinamensis (de Saussure) & & $\#$ \\
\hline 7 & Agelaia testacea (F.) & M L H & \\
\hline 8 & A. fulvofasciata (Degeer) & M L H & \# \\
\hline 9 & A. cajennensis (F.) & $\mathrm{H}$ & \\
\hline 10 & A. angulata (F.) & $\mathrm{L}$ & \# \\
\hline 11 & A. myrmecophila (Ducke) & LH & \\
\hline 12 & A. centralis (Cameron) & $\mathrm{MH}$ & \# \\
\hline 13 & Angiopolybia pallens (Lepeletier) & M L H & \# \\
\hline 14 & A. paraensis (Lepeletier) & M & \\
\hline 15 & Pseudopolybia difficilis (Ducke) & M & \\
\hline 16 & $\begin{array}{l}\text { Parachartergus fulgidipennis (de } \\
\text { Saussure) }\end{array}$ & & $\#(C)$ \\
\hline 17 & Protopolybia chartergoides (Gribodo) & $\mathrm{H}$ & $\#$ \\
\hline 18 & P. exigua (de Saussure) & L & \\
\hline 19 & P. bituberculata Silveira \& Carpenter & & $\#(C)$ \\
\hline 20 & Chartergus chartarius (Olivier) & & $\#$ \\
\hline 21 & C. metanotalis Richards & L & \\
\hline 22 & C. globiventris de Saussure & & $\#(C)$ \\
\hline 23 & Polybia bicyttarella Richards & $\mathrm{L}$ & \\
\hline 24 & P. platycephala Richards & LH & \\
\hline 25 & P. scrobalis Richards & $M L$ & \\
\hline 26 & P. dimorpha Richards & $M L$ & \\
\hline 27 & P. quadricincta de Saussure & M L H & \\
\hline 28 & P. jurinei de Saussure & LH & \\
\hline 29 & P. rejecta (F.) & & \# \\
\hline 30 & P.affinis du Buysson & M H & \# \\
\hline 31 & P. micans Ducke & M & \\
\hline 32 & P. velutina Ducke & & $\#(\mathrm{C})$ \\
\hline 33 & P. liliacea (F.) & $\mathrm{H}$ & \\
\hline 34 & P. striata (F.) & H & \\
\hline 35 & P. dimidiata (Olivier) & & $\#$ \\
\hline 36 & P. singularis Ducke & $M L$ & \# \\
\hline 37 & P. emaciate Lucas & M L H & \\
\hline 38 & P. procellosa dubitata Ducke & & \# \\
\hline 39 & Epipona tatua (Cuvier) & $\mathrm{H}$ & \\
\hline 40 & Synoeca virginea (F.) & $M L$ & \# \\
\hline 41 & S. surinama (L.) & M L H & \\
\hline \multirow[t]{2}{*}{42} & Metapolybia cingulata (F.) & H & \\
\hline & $\begin{array}{l}\text { Number of species registered with } \\
\text { method }\end{array}$ & 29 & 13 \\
\hline
\end{tabular}

(exclusive only) but this mostly reflected the numbers of Agelaia fulvofasciata, the commonest species.

The species lists from the two localities are very different, with only 18 species in common (Jaccard's similarity index = 26\%). In particular, one may note the 16 species of Polybia collected in Alvarães, a number two times larger than that obtained in Mamirauá. Furthermore, non detection of Angiopolybia paraensis and low frequency of Angiopolybia pallens in Mamirauá show that these two typical forest species probably do not find adequate habitat in the varzea. The proximal causal factors are unknown since both species construct aerial nests, a condition opposite to that of species like Agelaia angulata and Agelaia pallipes which are known to make nests in holes in the ground, and which were not found in the varzea. However, the data from Mamirauá show very clearly that other Agelaia species nesting in tree holes are not limited in the same way by the flooding cycle.

\section{AMAPÁ STATE}

Most of the interception traps (TMM or SUMH) in Região dos Lagos failed to capture any vespids, and active searches also had low productivity in finding individuals or social wasps nests in most sampling sites, with the general exception of those in the region of Pracuúba. Considering the entire transect from the Araguari River to Pracuúba (figure 3), only 31 species of 9 genera of polistines were collected (Polistinae; Table 4). Nearly all are common species with the exception of some Polistes, like P. goeldi and P. occipitalis which are rather less frequently encountered but not exactly rare. The two Mischocyttarus species found in the region of Pracuúba represent an extremely low number for this genus considering a local Amazonian fauna. The record of M. labiatus in the region of the Araguari River (tidal varzea environment) is actually dubious since it is based on the finding of an abandoned nest. On the other hand, the relatively large number of Polistes species is more or less typical of areas with significant occurrence of open vegetation.

In spite of the cursory character of the inventory, it seems clear that the number of species in Região dos Lagos is far less than the expected in areas of Terra firme forest. This becomes apparent by noting that only 6 species were collected in tidal varzea sites on the Araguari River system, and that a just slightly better result was obtained in mixed vegetation areas around Lago Novo (with grasslands, savanna, and secondary forest), with the recording of 11 species. On the other hand, 19 exclusive species (or 60\% of the total 31 species) were added through collecting in more western sites in the proximities of Pracuúba, a transitional area in close vicinity to the eastern limits of the Guyanan forests. Table 4 also shows that collecting effort in days was not too dissimilar between the three subregions ( 5 days for Araguari, 8 days for Lago Novo, and 7 days for Pracuúba). 


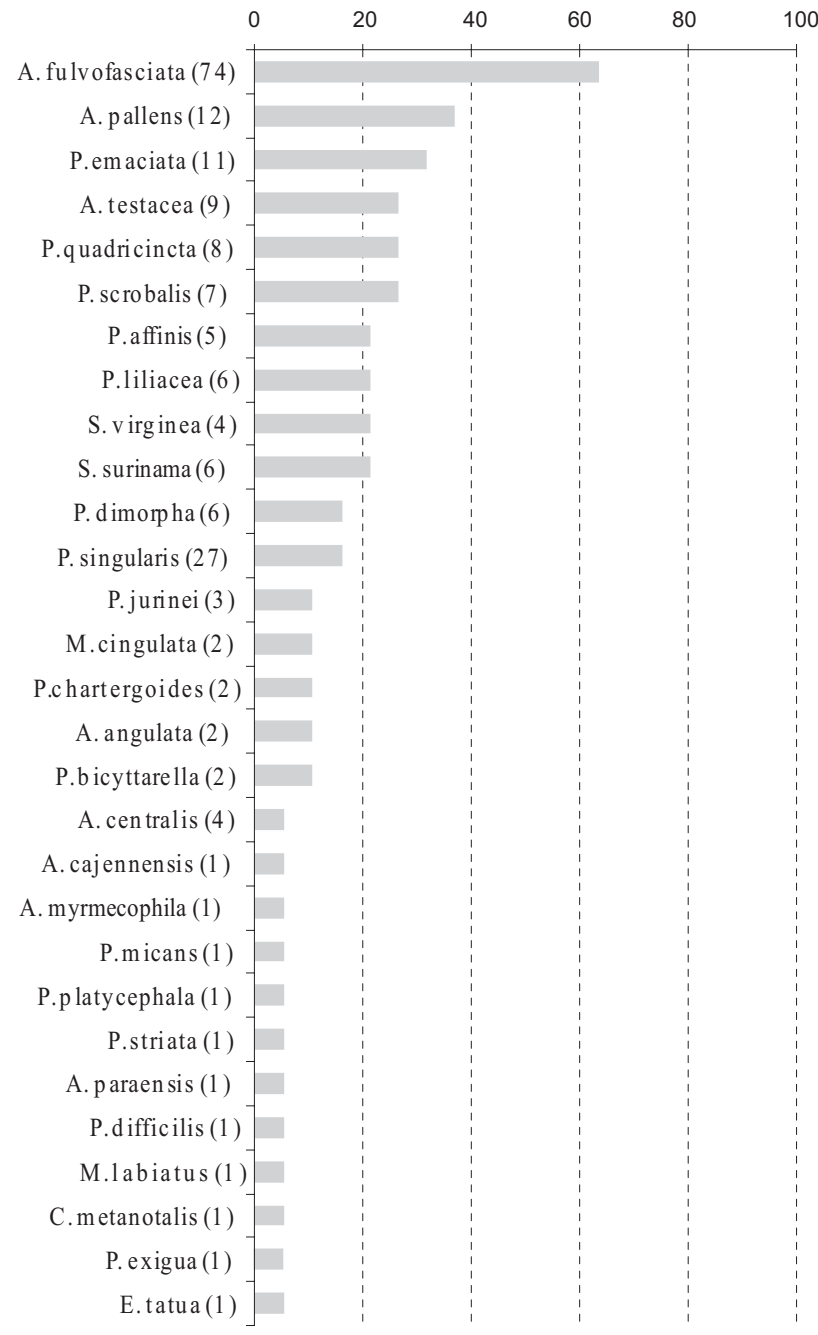

Figure $\mathbf{5}$ - Social wasp species composition and frequency in samples from Malaise and Suspended traps installed in terra firme habitats, in Alvarães, AM, Brazil, along three expeditions in 1993 and 1994. Number of collected individuals is shown in parenthesis.

Diversity patterns of social wasps in tidal varzea sites on Araguari River and other environments around Lago Novo were remarkable for the extreme rarefaction. Only a few very common inhabitants of open vegetation or forest edge were found with some frequency in these sites, like Polistes canadensis and Synoeca surinama. The nearly complete absence of species of Agelaia and Apoica was surprising given their commonness in various types of habitats across the Neotropics. These species only came to appear in sites within the Pracuúba region, together with other typical Amazonian species of genera like Angiopolybia and Leipomeles.

While less rich than vespid faunas of Terra firme habitats, the social wasp fauna of the varzea in Mamirauá proved to be quite expressive considering the strong limitations imposed by hydrological regime. Flooding of most parts of the varzea

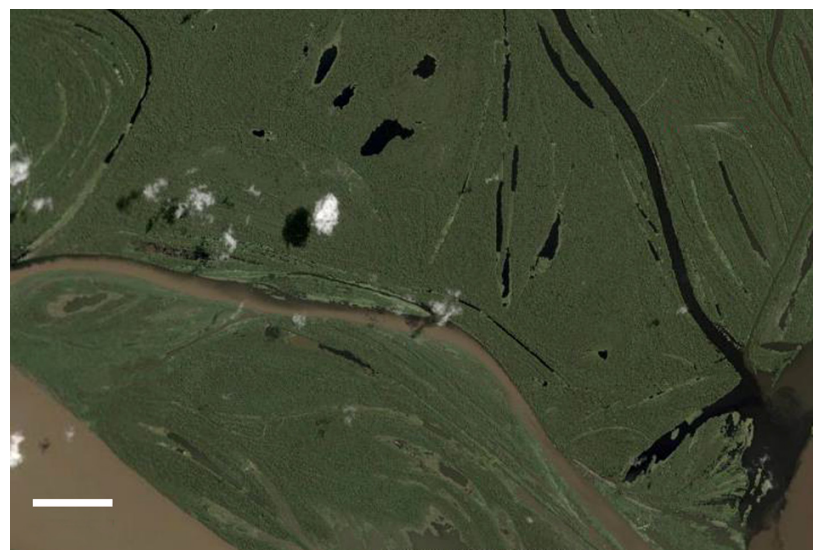

Figure 6. High resolution satellite image of the confluence region between Amazon and Japurá rivers, AM, Brazil, showing the relatively well preserved várzea forests. To the east is the channel of Mamirauá Lake near its mouth; scale bar is $1 \mathrm{~km}$ (http://earth.google.com).

for a period of at least four months prevents colonization of the area by species that nest in holes in the soil, and yet may influence the nest height patterns of those species constructing aerial nests. Species that preferably explore resources located on or near the ground surface would also be limited by the flooding cycle. In spite of such restrictions, the observed diversity patterns were remarkable when compared to other better known Amazonian sites. If the 42 species (found in 45 days of collecting) represent only half the species number encountered (in similar period of fieldwork) in a terra firme locality like Caxiuanã, in Pará (Silveira, 2002), the 15 genera collected in the varzea represent $80 \%$ of the genus level richness in the latter locality. In addition, a number of rare or uncommon species were found in Mamirauá, some of

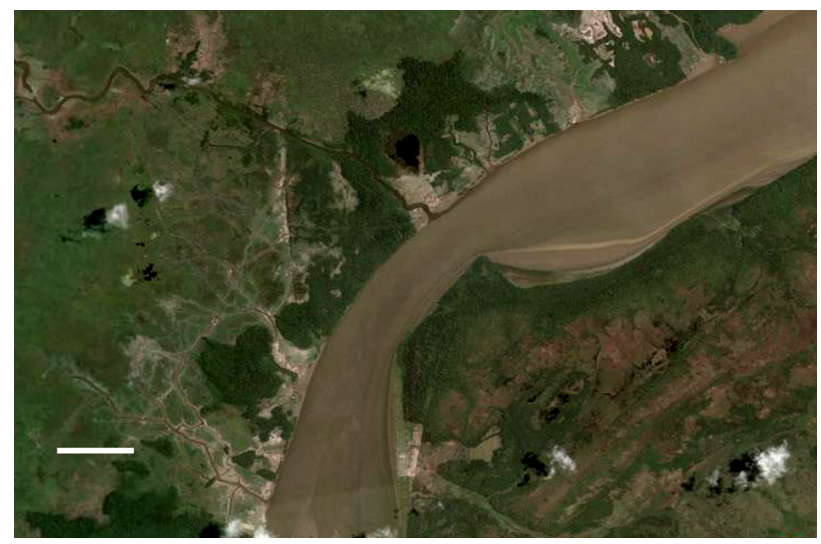

Figure 7 - High resolution satellite image of tidal várzea region of Araguari River, AP, Brazil, showing the largely altered landscape. Arrow points to mouth of Tabaco creek, one of the sampled localities; scale bar is $1 \mathrm{~km}$ (http://earth. google.com). 
Table 4 - Polistine wasps collected in Região dos Lagos, AP (April-May and October-November 2004); "F" is frequency as the fraction of sites in which a species has been collected. 19 sampling sites as follows: a- Tabaco Creek, varzea; b- Japim in Tabaco Creek, varzea; c- Piranhas Creek, varzea; d-Vista Alegre, varzea; e- Monte Sião, varzea; f- Comprido Lake, forested mound - meadow; g- São Benedito, lake margin - cerrado; h- Caranã, lake margin - cerrado; i- Tucunaré, riparian forest; j- 2 Km west of highway BR 156, cerrado - forest; $\mathrm{k}$ - Pernambuco settlement, cerrado - forest; l- end of Pernambuco road, forest; $m$ - Pantaleão's farm; $n$ - Lago Novo road, secondary forest; 0 - Entrada da Mata, forest; p- Rildo's farm, secondary forest; q- Mata do Flexal, riparian forest; y-Pracuúba city; z: Tartarugalzinho city.

\begin{tabular}{|c|c|c|c|c|c|c|c|c|c|c|c|c|c|c|c|c|c|c|c|c|c|}
\hline & \multirow{2}{*}{$\begin{array}{l}\text { Subregion } \\
\text { Species / Sampling site }\end{array}$} & \multicolumn{5}{|c|}{$\begin{array}{l}\text { Araguari (várzea) } \\
\text { (5 days) }\end{array}$} & \multicolumn{3}{|c|}{$\begin{array}{l}\text { L.Novo } \\
\text { (tesos) } \\
\text { (5 days) }\end{array}$} & \multicolumn{4}{|c|}{$\begin{array}{l}\text { L.Novo-Duas Bocas } \\
\text { ( } 3 \text { days) }\end{array}$} & \multicolumn{7}{|c|}{$\begin{array}{l}\text { Pracuúba-Pernambuco } \\
\text { (7 dias) }\end{array}$} & \multirow[t]{2}{*}{$\mathrm{F}(\%)$} \\
\hline & & $\mathrm{a}$ & $\mathrm{b}$ & $\mathrm{C}$ & $d$ & e & $f$ & $g$ & $\mathrm{~h}$ & $\mathrm{n}$ & 0 & $p$ & $z$ & $\mathrm{i}$ & j & $\mathrm{m}$ & $q$ & $\mathrm{y}$ & $\mathrm{k}$ & I & \\
\hline 1 & Agelaia angulicollis (Spinola) & & & & & & & & & & & & & & & & & & $\#$ & & 5 \\
\hline 2 & Agelaia cajennensis (F.) & & & & & & & & & & & & & $\#$ & & & & & $\#$ & & 11 \\
\hline 3 & Agelaia fulvofasciata (Degeer) & & & & & & & & & \# & & & & & & & & & $\#$ & & 11 \\
\hline 4 & Agelaia myrmecophila (Ducke) & & & & & & & & & & & & & & & & & & $\#$ & & 5 \\
\hline 5 & Agelaia pallipes (Olivier) & & & & & & & & & & & & & $\#$ & & & & & $\#$ & & 11 \\
\hline 6 & Angiopolybia pallens (Lepeletier) & & & & & & & & & & & & & $\#$ & \# & & $\#$ & & $\#$ & & 22 \\
\hline 7 & Apoica flavissima Van der Vecht & & & & & & & & & & & & & & & & & & & \# & 5 \\
\hline 8 & Apoica pallens (F.) & & & & & & & & & & & & & & & & & & & \# & 5 \\
\hline 9 & Apoica pallida (Olivier) & & & & & & & & & & & & & $\#$ & & & & & & $\#$ & 11 \\
\hline 10 & Apoica thoracica (Buysson) & & & & & & & & & & & & & & & & & & & $\#$ & 5 \\
\hline 11 & Brachygastra lecheguana (Latreille) & & & & & & $\#$ & & & & & & & & & & & & & & 5 \\
\hline 12 & Leipomeles dorsata (F.) & & & & & & & & & & & & & & & & & & $\#$ & & 5 \\
\hline 13 & $\begin{array}{l}\text { Mischocyttarus injucundus } \\
\text { (Saussure) }\end{array}$ & & & & & & & & & & & & & & & & & & $\#$ & & 5 \\
\hline 14 & Mischocyttarus labiatus Saussure & & & \# ? & & & & & & & & & & & & & & & $\#$ & & 5 \\
\hline 15 & Polistes billardieri (F.) & & & & & & & \# & & & & & & & & & & $\#$ & $\#$ & & 16 \\
\hline 16 & Polistes goeldi Ducke & & $\#$ & & & & & & & & & & & & & & & & & & 5 \\
\hline 17 & Polistes canadensis (L.) & $\#$ & $\#$ & & \# & & & \# & & & & $\#$ & \# & $\#$ & & & & & & & 38 \\
\hline 18 & Polistes carnifex rufipennis Latreille & & & & & & $\#$ & & & & & & & $\#$ & & & & & $\#$ & & 16 \\
\hline 19 & Polistes ociipitalis Ducke & & & & & & & & & & & & & & & & & & $\#$ & & 5 \\
\hline 20 & Polistes testaceicolor Bequaert & & & & & & & & & & $\#$ & & & & & & & & & & 5 \\
\hline 21 & Polistes versicolor (Olivier) & & & & & & & & & & $\#$ & & & $\#$ & $\#$ & & & & & & 16 \\
\hline 22 & Polybia bicyttarella Richards & & & & & & & & & & & & & $\#$ & & & & & $\#$ & & 11 \\
\hline 23 & Polybia chrysothorax (Lichtenstein) & & & & & $\#$ & & & & & & & & & & & & & & & 5 \\
\hline 24 & Polybia dimidiata (Olivier) & & & & & & & & & & & & & & & & & & $\#$ & & 5 \\
\hline 25 & Polybia sp. gr. occidentalis & & & & & & & & & & & & & & $\#$ & & & & & & 5 \\
\hline 26 & Polybia micans Ducke & & & & & & & & & & & & & \# & & & & & & & 5 \\
\hline 27 & Polybia occidentalis (Olivier) & & \# & & & \# & $\#$ & \# & & & & & & & & & & & & & 22 \\
\hline 28 & Polybia rejecta (F.) & & \# & & & \# & & \# & & & & & & & & & & & & & 16 \\
\hline 29 & Polybia sericea (Olivier) & & & & & & & \# & & & & & & \# & & \# & & & & & 16 \\
\hline 30 & Polybia striata (F.) & & & & & & & & & & & & & & & $\#$ & & & & & 5 \\
\hline 31 & Synoeca surinama (L.) & & \# & \# & & & $\#$ & \# & & & & $\#$ & & \# & & $\#$ & & & & & 38 \\
\hline & Number of species per site & 1 & 5 & 2 & 1 & 3 & 4 & 6 & - & 1 & 2 & 2 & 1 & 11 & 3 & 3 & 1 & 1 & 14 & 4 & \\
\hline
\end{tabular}

them with surprising regularity as was the case of Clypearia weyrauchi. Other species like Agelaia fulvofasciata and Polybia rejecta presented extremely high levels of abundance in most places, the latter species being frequently found along channel margins in large multispecies associations including colonies of Azteca ants and nests of the bird Cacicus cela. Authors have stated that varzea forests are more species rich than other floodplain ecosystems like the igapó forests encountered along black-water rivers, and that have higher productivity than any other Amazonian ecosystem. Values of primary production may be two to three times higher than those verified in Terra firme forests (Parolin et al., 2004). The impracticability of construction of species accumulation curves with the data at hand prohibits more accurate estimation of the total number of wasp species in Mamirauá. However, the fact that a significant $26 \%$ (11 species) of the species were added in the 
last expedition suggests that an important fraction of more rare species still wait for being discovered.

The most thorough inventory of social wasps in Amapá to date was made by Silveira \& collaborators (2001; unpublished) with finding of 78 species in the region of the Cajari River, a complex area with prevalence of terra firme forests but presenting extensive spots of savanna formations. A similar species number was not to be expected in Região dos Lagos, a coastal area mainly covered with open vegetation types and mangrove. However, the very low diversity actually found was below the worst expectations. In spite of the relatively low effort and narrow seasonal reach of the survey, the virtual absence of otherwise common wasp species in environments like tidal varzea forests along the Araguari River must be considered as truly remarkable.

The causes of low diversity in Região dos Lagos are probably related to isolation and relative immaturity of the region, allied to strong degradation of forested habitats. As already shown by data from Mamirauá, flooding may be an important factor restraining colonization of varzea by some social wasps, but it does not prevent the establishment there of an expressive fauna, with several species attaining high abundance levels. However, great differences exist between such a continental stretch of Amazon varzea at one side and estuarine tidal systems like that of Araguari River, from levels of ecosystem productivity to biogeographical controlling factors.

Região dos Lagos appears as a large marginal sector separated from the central Amapá forests by a north-south belt of relatively restrictive savanna habitats, narrower to the north at Flexal River and wider to the south at Araguari River (Figure 3). It is expected from such a spatial configuration that aspects like distance from the main source of species (Terra Firme forest) and commonness of appropriate habitats (varzea forest, forested mounds in lacustrine areas, ciliary forests in areas of savanna) play a central part as factors controlling insect diversity in the area. Superimposed on these factors, human activity, especially logging and water buffalo ranching have certainly had strong depressing effects upon biodiversity in the region (Santos, 2006). Differences between the scenario just described and a typical Amazon varzea like Mamirauá can be immediately apprehended. In respect to position relative to the species source, Mamirauá may be considered as just embedded within surrounding Terra firme forests (it seems improbable that rivers have acted as barriers to dispersal

Table 5 - Eumenine wasps collected in Região dos Lagos, AP (April-May and October-November 2004); "F" is the frequency as the fraction of sites in which a species has been collected. Legends for 19 sampling sites as follows: a- mouth of Tabaco Creek, varzea; b- Japim in Tabaco Creek, varzea; c- Piranhas Creek, varzea; d- Vista Alegre, varzea; e- Monte Sião, varzea; f- Comprido Lake, forested mound - meadow; g- São Benedito, lake margin - cerrado; h- Caranã, lake margin - cerrado; i- Tucunaré, riparian forest; j- $2 \mathrm{Km}$ west of highway BR 156, cerrado forest; k- Pernambuco settlement, cerrado - forest; l- end of Pernambuco road, forest; m- Pantaleão's farm; n- Lago Novo road, secondary forest; o- Entrada da Mata, forest; p- Rildo's farm, secondary forest; q- Mata do Flexal, riparian forest; y- Pracuúba city; z: Tartarugalzinho city.

\begin{tabular}{|c|c|c|c|c|c|c|c|c|c|c|c|c|c|c|c|c|c|c|c|c|c|}
\hline & \multirow{2}{*}{$\begin{array}{l}\text { Subregion } \\
\text { Species / Sampling site }\end{array}$} & \multicolumn{5}{|c|}{$\begin{array}{l}\text { Araguari (várzea) } \\
\text { (5 days) }\end{array}$} & \multicolumn{3}{|c|}{$\begin{array}{l}\text { L.Novo (tesos) } \\
\text { ( } 5 \text { days) }\end{array}$} & \multicolumn{4}{|c|}{$\begin{array}{l}\text { L.Novo-Duas } \\
\text { Bocas } \\
\text { ( } 3 \text { days }) \\
\end{array}$} & \multicolumn{7}{|c|}{$\begin{array}{l}\text { Pracuúba-Pernambuco } \\
\text { (7 dias) }\end{array}$} & \multirow[t]{2}{*}{$\mathrm{F}(\%)$} \\
\hline & & $\mathrm{a}$ & $\mathrm{b}$ & $\mathrm{C}$ & $d$ & $\mathrm{e}$ & $f$ & $g$ & $\mathrm{~h}$ & $\mathrm{n}$ & 0 & $p$ & $\mathrm{z}$ & $\mathrm{i}$ & j & $\mathrm{m}$ & $q$ & $y$ & $\mathrm{k}$ & 1 & \\
\hline 1 & Alphamenes sp & & & & & & & \# & & & & & & & & & & & & & 5 \\
\hline 2 & Monobia angulosa Saussure & & & & & & & & & & & & & \# & & & & & & & 5 \\
\hline 3 & Montezumia azurescens (Spinola) & & & & & & \# & \# & & & \# & & & & & & & & & & 16 \\
\hline 4 & Montezumia nigriceps (Spinola) & & & & & & & & & & & \# & & & & & & & & & 5 \\
\hline 5 & Montezumia pelágica Saussure & & & \# & & & & & & & & & & & & & & & & & 5 \\
\hline 6 & Omicron sp 1 & & & & & & & & & \# & & & & \# & & & & & & & 11 \\
\hline 7 & Omicron sp 2 & & & \# & & & & & & & & & & & & & & & & & 5 \\
\hline 8 & Pachodynerus sp 1 & & & & & & \# & & & & & & & & & & & & & & 5 \\
\hline 9 & Pachodynerus sp 2 & & & & & & \# & & & & & & & & & & & & & & 5 \\
\hline 10 & Zeta argillaceum (L.) & & & & & & \# & & & & & & & & & & & & & & 5 \\
\hline 11 & Zethus brasiliensis fuscatus Bequaert & & & & & & & & & & \# & \# & & & & & & & & & 11 \\
\hline 12 & Zethus mexicanus mexicanus (L.) & & & & & & & \# & & & & & & & & & & & & & 5 \\
\hline 13 & Zethus pallidus Smith & & & & & & & & & & & & & & & & & & \# & & 5 \\
\hline 14 & Zethus smithii Saussure & & & & & & & & & & & & & & & \# & & & & & 5 \\
\hline
\end{tabular}


of social wasp species in Amazonia in the same way as for vertebrates). Second, geochemistry aspects and dynamics of varzea land buildup are also certainly much more exuberant in the Amazon (Sioli, 1984; Mayorga \& Aufdenkampe, 2002; Mertes et al., 1996), thus originating more extensive and richer soils capable of supporting vast areas covered by forests (which in more elevated sites may indeed be similar to terra firme forests; Ayres, 1993). On the other hand, Amapá rivers like the Araguari originate on the ancient and highly eroded terrains of the Guyana Shield and carry a much lower charge of sediments, with marginal levees being considerably narrower and probably less fertile than Amazon varzea "restingas". In addition to these natural aspects, alteration of forested habitats by human activity has been considerably more severe in Região dos Lagos (compare the recent satellite images of figures 6 and 7; http://earth.google.com).

Some other Hymenoptera presented similar patterns of species poverty in the Araguari tidal varzea region. Only two solitary eumenine wasps were collected there, compared to nine species in Lago Novo and four species in the Pracuúba region (Table 5). With regard to eusocial meliponines, Melipona compressipes (F.) was the sole species found. Compared to this, a collection of stingless bees from the varzea in Mamirauá contains at least twelve species (MPEG collection).

\section{ACKNOWLEDGMENTS}

The authors are gratefull to "Sociedade Civil Mamirauá" and to Dr. Inocêncio Gorayeb (Museu Paraense Emílio Goeldi) for providing the opportunity of collecting in Mamirauá, Amazonas. We also thank the Brazilian Ministry of the Environment (MMA) and PROBIO for financial support to the biological inventory work in Amapá State.

\section{LITERATURE CITED}

Ayres, J. M. 1993. As matas de várzea do Mamirauá: Médio rio Solimôes. Sociedade Civil Mamirauá, Brasília, DF. 123pp.

Carpenter, J. M.; Wenzel, J. W.; Kojima, J. 1996. Synonymy of the Genus Occipitalia Richards, 1978, with Clypearia de Saussure, 1954 (Hymenoptera: Vespidae; Polistinae, Epiponini). Journal of Hymenopterological Research, 5: 157-165.

Cattanio, J. H.; Anderson, A. B.; Carvalho, M. S. 2002. Floristic composition and topographic variation in a tidal floodplain forest in the Amazon Estuary. Revista Brasileira de Botânica, 25: 419-430.

Colwell R.K.; Coddington, J.A. 1994. Estimating terrestrial biodiversity through extrapolation. Philophical Transactions of the Royal Society, 345: 101-118.

Fonseca, G.A.B. 2001. Proposta para um programa de avaliação rápida em âmbito nacional. In: I. Garay e B. Dias (eds),
Conservação da Biodiversidade em Ecossistemas Tropicais. Editora Vozes, Petrópolis. p. 150-156.

Koziell, I.; Inoue, C.Y.A. 2006. Mamirauá Sustainable Development Reserve, Brazil. Lessons learnt in integrating conservation with poverty reduction. Biodiversity and Livelihoods, 7: 1-72.

Mayorga, E.; Aufdenkampe, A. 2002. Processing of bioactive elements in the Amazon River system. In: McClein, M. E. (ed.) The Ecohydrology of South American Rivers and Wetlands. International Association of Hydrological Sciences Special Publication no. 6, Wallingford, Oxfordshire, p. 1-24.

Mertes, L.A.K.; Dunne, T.; Martinelli, A. 1996. Channel-floodplain geomorphology along the Solimões-Amazon River, Brazil. Geological Society of America Bulletin, 108: 1089-1107.

Miranda, E.E.; Coutinho, A. C. 2004. Brasil Visto do Espaço. Campinas: Embrapa Monitoramento por Satélite, 2004. Disponível em: http://www.cdbrasil.cnpm.embrapa.br

Parolin, P.; Ferreira, L.V.; Albernaz, A.L.K.M.; Almeida, S.S. 2004. Tree species distribution in varzea forests of Brazilian Amazonia. Folia Geobotanica, 39: 371-383.

Pickett, K.M.; Wenzel, J.W. 2007. Revision and cladistic analysis of the nocturnal social wasp genus, Apoica Lepeletier (Hymenoptera: Vespidae; Polistinae, Epiponini). American Museum Novitates, 3562: 1-30.

Pires, J.M.; Prance, G.T. 1985. The vegetation types of the Brazilian Amazon. In: Prance, G.T.; Lovejoy, T.E. (eds.) Key Environments: Amazonia. Pergamon Press, Oxford, p. 109-145.

Queiroz, H.L. 2005. A reserva de desenvolvimento sustentável Mamirauá. Estudos Avançados, 19: 183-203.

Richards, O.W. 1971. The biology of the social wasps (Hymenoptera, Vespidae). Biological Review, 46: 483-528.

Richards, O.W. 1978. The social wasps of the Americas excluding the Vespinae. British Museum (Natural History), London.580 pp

Santos, V.F. 2006. Ambientes Costeiros Amazônicos: Avaliação de Modificaçôes por Teledetecção. Universidade Federal Fluminense-UFF/LAGEMAR. Geologia e Geofísica Marinha.

Santos, V.F.; Figueiredo Jr., A.G.; Silveira, O.F.M.; Polidori, L.; Oliveira, D.M.; Dias, M.B.; Santana, L.O. 2005. Processos Sedimentares em áreas de macro-marés influenciados pela pororoca - estuário do rio Araguari-Amapá-Brasil. In: X Congresso ABEQUA. Guarapari-ES, Cd-ROM. 6p.

Silveira, O.F.M. 1998. A Planície costeira do Amapá: dinâmica de ambiente costeiro influenciado por grandes fontes fluviais quaternárias. Tese de Doutorado, Universidade Federal do Pará, Belém, PA. 215pp.

Silveira, O.F.M. 2006. Aspectos Geológicos-Geomorfológicos da Região Costeira entre o Rio Amapá Grande e a Região dos Lagos do Amapá. In: Costa Neto, S.V. (org.) Inventário Biológico das áreas do Sucuriju e Região dos Lagos no Estado do Amapá. PROBIO/MMA - IEPA/AP, Macapá, p. 17-40.

Silveira, O.T. 2002. Surveying neotropical social wasps. An evaluation of methods in the Ferreira Penna Research Station 
(ECFPn), in Caxiuanã, PA, Brazil (Hym., Vespidae, Polistinae). Papéis Avulsos de Zoologia, 42: 299-323.

Sioli, H. 1984. The Amazon and its main affluents: Hydrography, morphology of the river courses, and river types. In: Sioli H., (ed.) The Amazon, limnology and landscape ecology of a mighty tropical river and its basin. Junk Publ., Dordrecht. p. 127-165
Wittmann, F.; Junk, W.J.; Piedade, M.T.F. 2004. The varzea forests in Amazonia: flooding and the highly dynamic geomorphology interact with natural forest succession. Forest Ecology and Management, 196: 199-212.

Recebido em 25/07/2007

Aceito em 16/01/2008 